\title{
RESIDUAL SEISMIC CAPACITY OF DUCTILE RC FRAME WITH WING WALLS BASED ON FULL-SCALE LOADING TEST
}

\author{
Tomohisa Mukai ${ }^{1}$, Toshikazu Kabeyasawa ${ }^{2}$, Masanori Tani ${ }^{3}$, \\ Haruhiko Suwada ${ }^{4}$ and Hiroshi Fukuyama ${ }^{5}$
}

(Submitted March 2017; Reviewed August 2017; Accepted October 2017)

\begin{abstract}
In order to use a damaged building continuously after earthquake, owners and/or stakeholders need to understand residual seismic capacity of the building. In Japan, a method to evaluate residual seismic capacity for damaged buildings had been developed. In order to evaluate residual seismic capacity of damaged building, the damage level of structural elements should be evaluated properly. This paper presents the results of damage analysis based on experimental data obtained from a full-scale static loading test [1] on a five-story reinforced concrete building tested at Building Research Institute. The damage rating for the specimens evaluated by the residual seismic capacity concept [3] was "Moderate" or "Heavy" at $0.5 \%$ and $1 \%$ building drift angle despite the structure maintaining horizontal load carrying capacity. This implies that the applied method gives a conservative result for ductile buildings, such as relatively new moment resisting frames designed after 1981. In order to apply the method used in this paper to new buildings, the damage evaluation method for structural elements should be advanced more in the future.
\end{abstract}

\section{INTRODUCTION}

When severe earthquake occurs, some buildings have several damages and the original seismic performance deteriorates. After earthquake, owners and/or users need to understand damage level of their damaged buildings to determine whether they can continuously use the building. In Japan, an existing standard describes a method to evaluate damage level of RC buildings using residual seismic capacity ratio which is defined as the ratio of the seismic capacity of the damaged building under earthquake to the original seismic capacity [1] The evaluation method was developed based on the residual seismic capacity obtained from the damage data of actual damaged buildings due to past severe earthquake. However, investigations on residual seismic capacity of full-scale ductile $\mathrm{RC}$ frame specimens have never been carried out. This paper shows the results from damage rating of an entire building structure evaluated by the residual seismic capacity concept based on the standard in Japan and the validity of the method is discussed.

\section{LOADING TEST}

A static loading test on a full-scale reinforced concrete building was carried out as described in the past paper [2]. The specimen is a full-scale five story reinforced concrete building with 2 bays in the loading direction and one bay in the transverse direction, and was constructed in a laboratory of Building Research Institute at Tsukuba. The elevation of the specimen is shown in Fig.1. The story height is $3.5 \mathrm{~m}$ and the total height of the specimen is $17.5 \mathrm{~m}$ (Fig.1). The span length is $6.0 \mathrm{~m}$ in both directions. There are two types of openings $(2.0 \mathrm{~m} \times 1.8 \mathrm{~m}$ and $1.0 \mathrm{~m} \times 1.8 \mathrm{~m})$ symmetrically positioned on the walls along the loading direction. There are structural gaps provided at the end of the openings as shown in Fig.2 (a). The vertical walls between openings are completely separated from the main frame by those gaps.

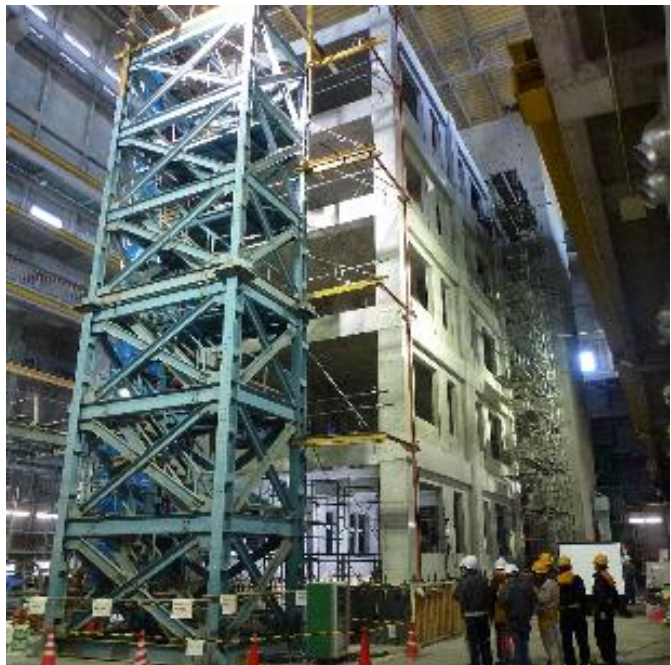

Figure 1: Panoramic view of the 5 story specimen.

The beam cross-section is $500 \times 700 \mathrm{~mm}$ with eight $\mathrm{D} 25$ bars ( $2^{\text {nd }}$ to $4^{\text {th }}$ floor), or six D25 bars ( $5^{\text {th }}$ and top floor) as longitudinal reinforcement shown in Fig.3. Stirrups are D13 at $100 \mathrm{~mm}$ or $150 \mathrm{~mm}$ spacing. All slab thickness is $200 \mathrm{~mm}$, the top and bottom of the slab reinforcement are D10 bars at 150 $\mathrm{mm}$ spacing, but D13 is arranged alternatively with D10 bars for the top reinforcement in the transverse loading direction. The lap splice of the reinforcement is provided in the middle of the span, and the end of the top reinforcement is anchored to the transverse beams with 90-degree hooks. The anchorage length of the bottom reinforcement is $250 \mathrm{~mm}$ from the side surface of the transverse beam.

\footnotetext{
1 Corresponding Author, Senior Research Engineer, Building Research Institute, Tsukuba, t_mukai@kenken.go.jp

2 Associated Professor, Tokyo Metropolitan University,Tokyo, tosikazu@tmu.ac.jp

3 Associated Professor, Kyoto University, Kyoto, tani@archi.kyoto-u.ac.jp

4 Senior Research Engineer, National Institute for Land and Infrastructure Management, Tsukuba, suwada-h92h9@mlit.go.jp

5 Director, National Institute for Land and Infrastructure Management, Tsukuba, fukuyama-h92ta@mlit.go.jp
} 


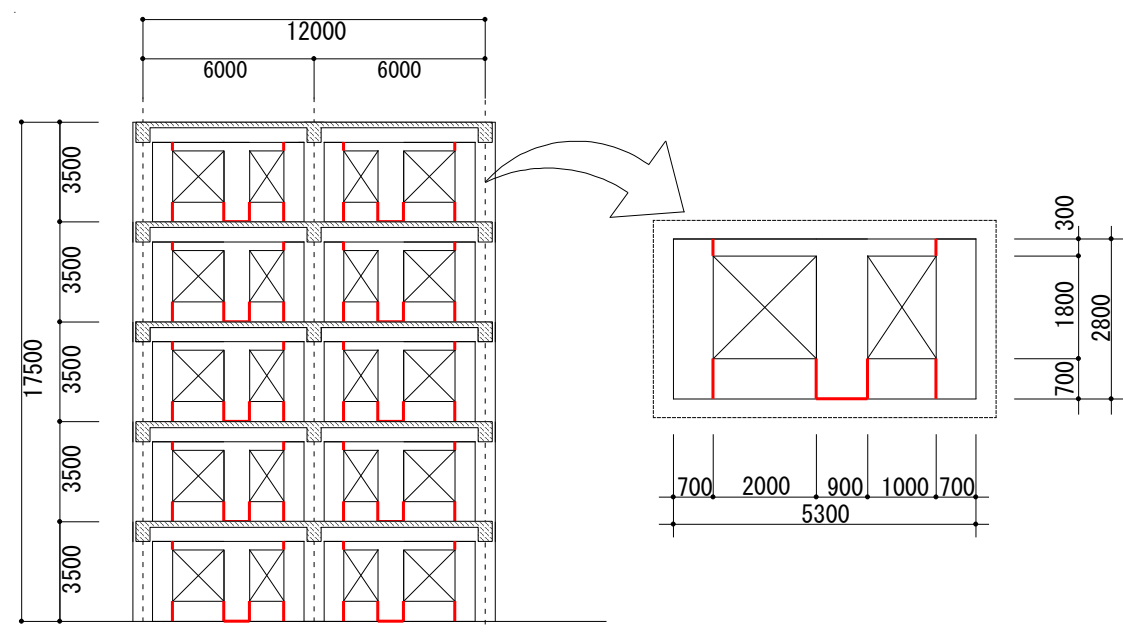

(a) loading direction

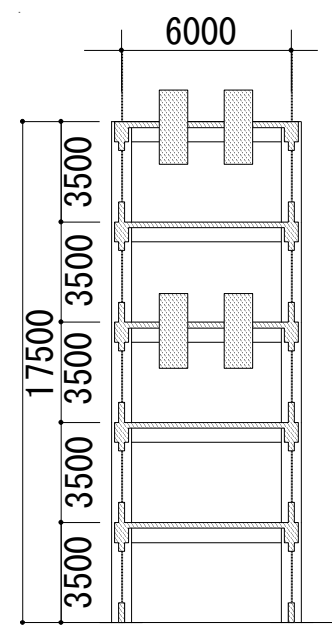

(b) loading transverse direction

Figure 2: Elevation of the specimen.

Columns are $700 \mathrm{~mm}$ square sections with sixteen D25 bars as longitudinal reinforcement shown in Fig.4. The hoops are two sets of D13 reinforcement and D13 sub-tie at $100 \mathrm{~mm}$ spacing $\left(1^{\text {st }}\right.$ and $2^{\text {nd }}$ story). Steel type of longitudinal reinforcing steel for columns excepting $1^{\text {st }}$ story is SD390 and one at $1^{\text {st }}$ floor is
SD345. Steel type of shear reinforcement is SD295. The length of the wing walls is $700 \mathrm{~mm}$ and the thickness is 200 $\mathrm{mm}$ shown in Fig.4. The end of the wing wall section is specially arranged with six D16 longitudinal bars confined by hoops to prevent buckling of the longitudinal bars. The

2650

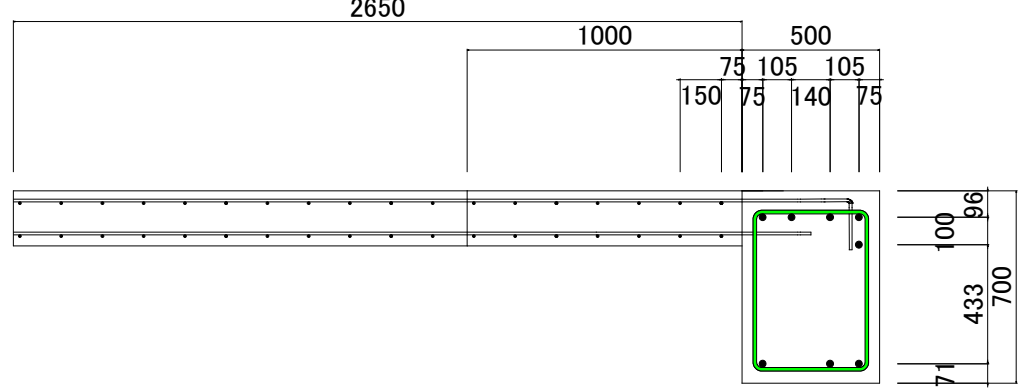

\begin{tabular}{|c|c|}
\hline Longitudinal bar of beam at 2nd-4th floor & 8-D25(SD345) \\
\hline Shear reinforcement of beam at 2nd-4th floor & 2-D13(SD295)@100 \\
\hline Slab reinforcement at 2nd-4th floor (loading direction) & 2-D10(SD295)@150 \\
\hline $\begin{array}{c}\text { Slab reinforcement at 2nd-4th floor (loading orthogonal } \\
\text { direction) }\end{array}$ & $\begin{array}{c}\text { D10(SD295)@150 for bottom reinforcement } \\
\text { ※D13(SD295)@ 150 for top reinforcement alternates with D10 }\end{array}$ \\
\hline
\end{tabular}

(a) 2nd to 4th floor

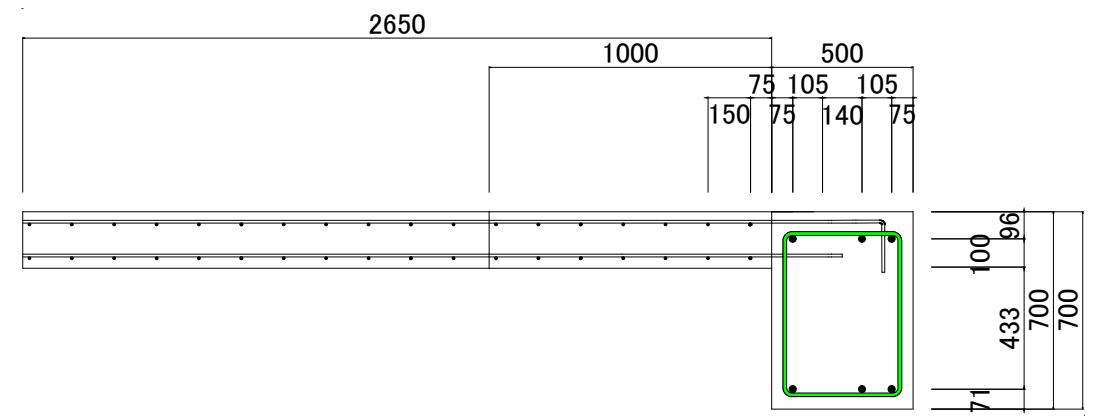

\begin{tabular}{|c|c|}
\hline Longitudinal bar of beam at 5th-top floor & 6-D25(SD345) \\
\hline Shear reinforcement of beam at 5th-top floor & 2-D13(SD295)@ 200 \\
\hline Slab reinforcement at 5th-top floor & Same as 2 ${ }^{\text {nd }}$ to 4 ${ }^{\text {th }}$ floor \\
\hline
\end{tabular}

(b) 5th to top floor

Figure 3: Section and reinforcement details of beams with slabs. 


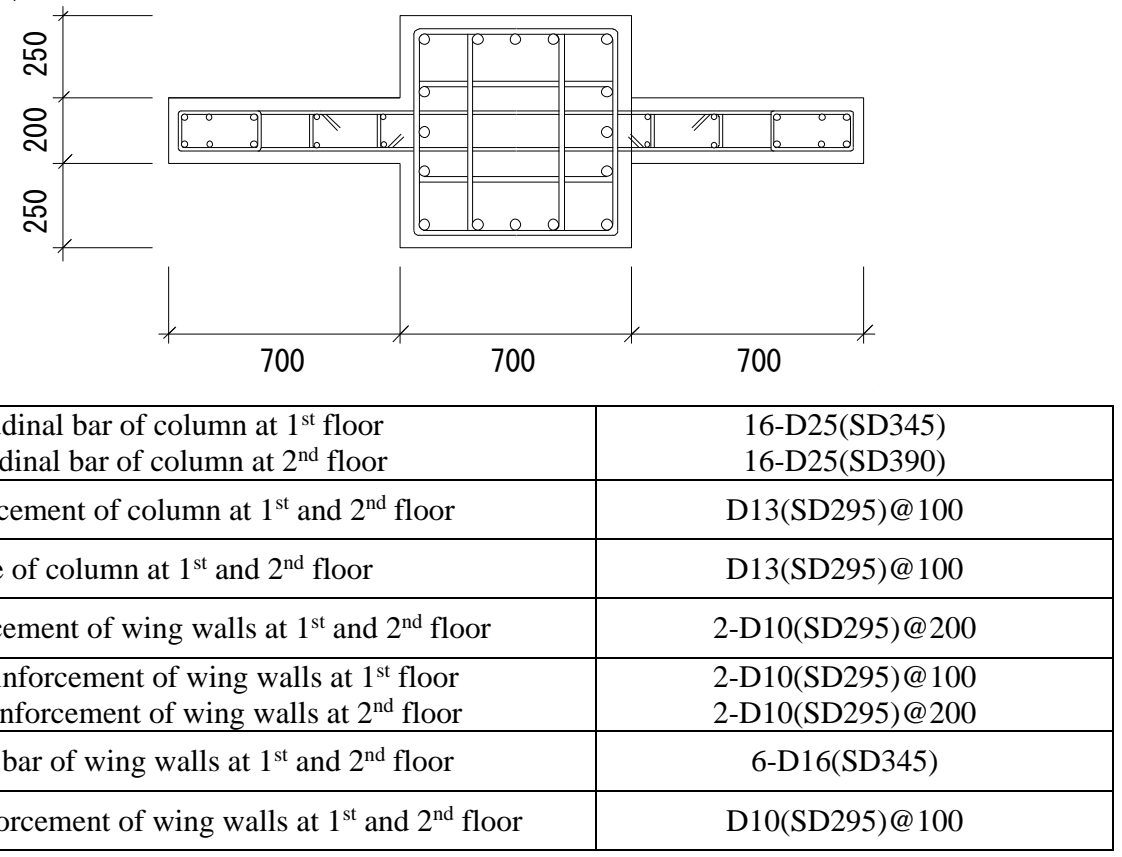

(a) 1st and 2nd floor

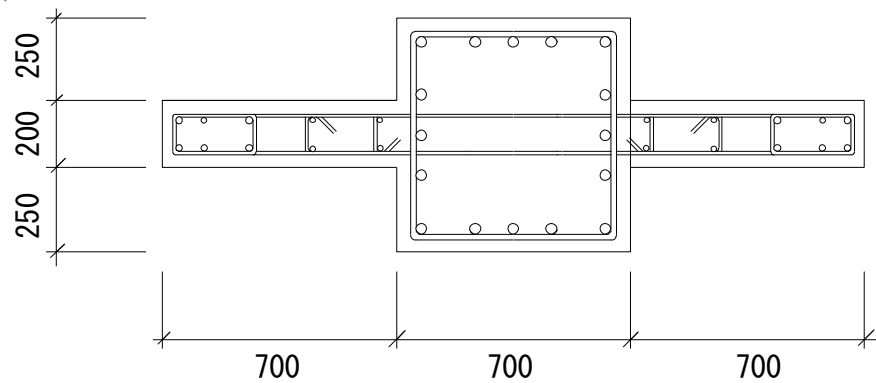

\begin{tabular}{|c|c|}
\hline Longitudinal bar of column at 3rd-5th floor & 16-D25(SD390) \\
\hline Shear reinforcement of column at 3rd-5th floor & D13(SD295)@100 \\
\hline Sub-tie of column at 3rd-5th floor & - \\
\hline Vertical reinforcement of wing walls at 3rd-5th floor & 2-D10(SD295)@200 \\
\hline Horizontal reinforcement of wing walls at 3rd-5th floor & 2-D10(SD295)@200 \\
\hline Longitudinal bar of wing walls at 3rd-5th floor & 6-D16(SD345) \\
\hline Confinement reinforcement of wing walls at $1^{\text {st }}$ and $2^{\text {nd }}$ floor & D10(SD295)@ 200 \\
\hline
\end{tabular}

(b) $3^{\text {rd }}$ to $5^{\text {th }}$ floor

Figure 4: Section and reinforcement details of columns with wing walls.

vertical reinforcement in the wall section is double layers of D10 bars at $200 \mathrm{~mm}$ spacing, which is confined by a set of horizontal reinforcements. The horizontal reinforcement (D10) in the wall section is anchored into the column section without hook and into the wing wall section with 180-degree hook. The spacing of this horizontal reinforcement is $100 \mathrm{~mm}$ for the $1^{\text {st }}$ story, and $200 \mathrm{~mm}$ for other stories.

Fig. 5 shows the attachment of the actuators on the top floor. Eight actuators are used during the test, with a series of 4 actuators located on the roof level and 4th floor level respectively. The maximum capacity of each actuator is 1000 $\mathrm{kN}$ with a stroke of $\pm 500 \mathrm{~mm}$. The load distribution ratio of top floor and $4^{\text {th }}$ floor is 1 to 2 to match the base shear and overturning moment at $1^{\text {st }}$ floor under an inverted triangle shape horizontal load distribution. The force of the actuators is measured by load cells. Two actuators at the top of the specimen are controlled by horizontal displacement at the top floor and the other actuators follow the load of those two actuators. Loading history is cyclic loading toward each target value of building drift angle, which is equal to horizontal displacement at top floor divided by total height. There is one cycle at each of $0.0625 \%$ and $0.125 \%$ drift, and two cycles at each of $0.25 \%, 0.5 \%, 1.0 \%, 1.5 \%$ and $2.0 \%$ drift. Story drift is measured by displacement transducers. Local displacements such as moment curvature and shear deformation are measured for the $1^{\text {st }}$ story columns and $2^{\text {nd }}$ floor beams. The strain in the reinforcement for beams, slabs, columns, and wing walls are measured by strain gauges. The maximum widths of every visible crack on structural elements are also measured by 

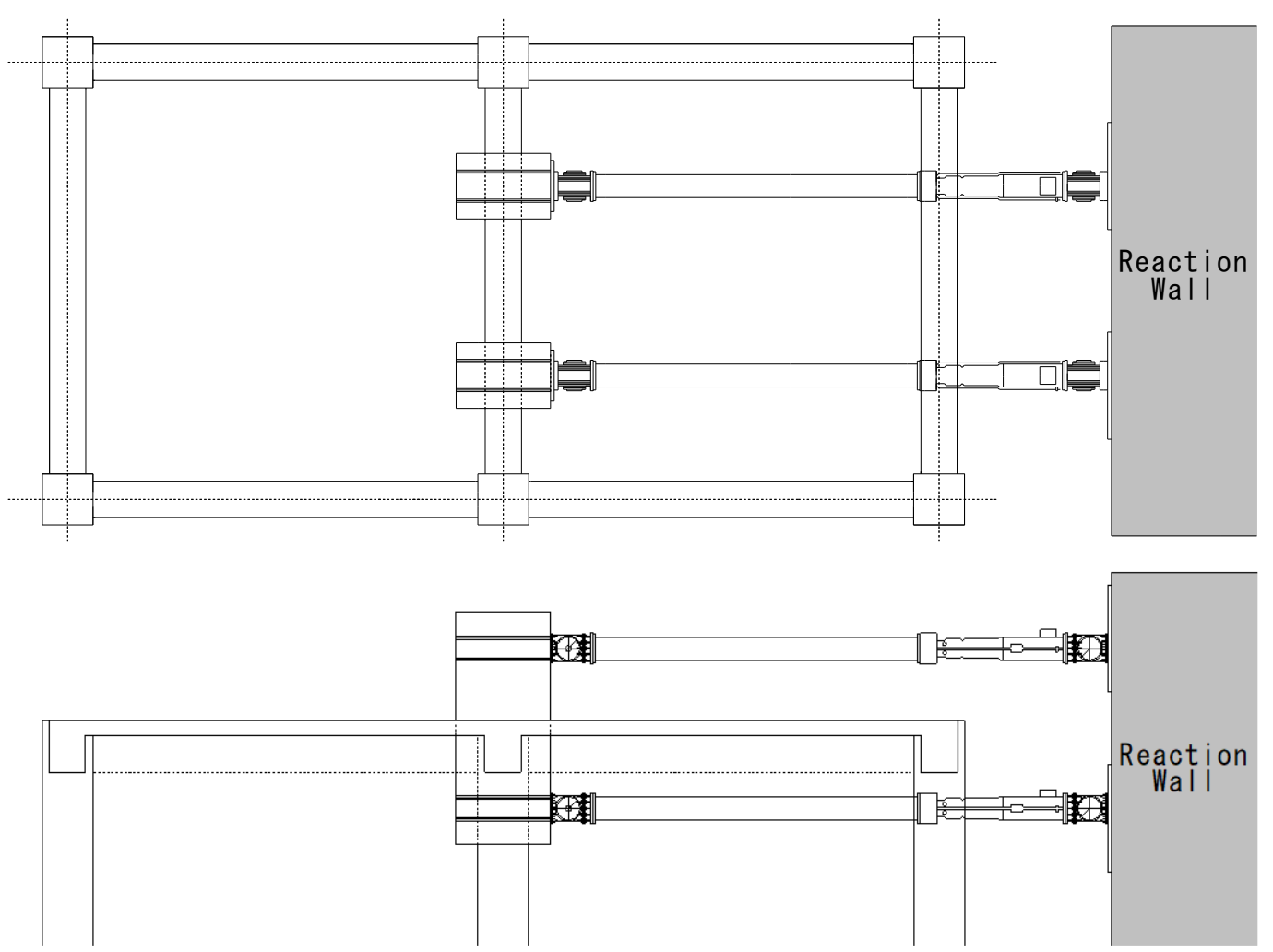

Figure 5: Loading set up on the roof level.

crack scale. Crack width measurement was performed at peak displacement and unloading during the second negative loading cycle (the first cycle for $R=0.0625$ and $0.125 \%$ ) for all visible cracks.

\section{RESULTS OF THE FULL SCALE TEST}

Fig.6 shows the load displacement relationship between the building drift angle and base shear. Increment of the base shear after $1.0 \%$ drift is gradual due to formulation of collapse mechanism for the system level. The columns with wing wall normally show strength deterioration after compression failure, which is defined as crush of core concrete, at the end of wing wall, but this frame shows ductile behavior until ultimate state, since the contribution of the beam members are dominant. The strength and stiffness increase locally due to the closing of the structural gap between center hanging vertical walls and spandrels after $1.5 \%$ drift. The inverted Sshape slip behavior appeared in $2^{\text {nd }}$ cycle of loading. The maximum base shear due to beam side sway mechanism is $4654 \mathrm{kN}$ in calculation, which is consistent with the maximum strength $(4489 \mathrm{kN})$ before the conflict of center hanging walls

Fig.7 shows cracking patterns of the specimen at $0.5 \%$ drift and ultimate state. Representative cracking damage at each peak drift is as follows. Flexural cracking on beam and floor slab is observed around the gap, and flexural cracks are also observed in $1^{\text {st }}$ story columns at $0.125 \%$ drift. Flexural cracks are observed at the bottom of $2^{\text {nd }}$ story column, and at the top of the $3^{\text {rd }}, 4^{\text {th }} 5^{\text {th }}$ story columns at $0.25 \%$. At $0.5 \%$ drift, flexural cracks on beams are observed and the width of those cracks increases, but the number of the cracks does not increase significantly from $0.25 \%$ drift. The compression failure of the wing wall concrete section is observed at $1.0 \%$ drift. Buckling of the longitudinal reinforcement for columns with wing wall are observed at $1.5 \%$ drift. Also, bending shear cracks occur by the conflict of center hanging vertical walls and spandrels in $1^{\text {st }}, 2^{\text {nd }}, 3^{\text {rd }}$ story at $1.5 \%$ drift. The same bending shear crack occurs in $4^{\text {th }}$ and $5^{\text {th }}$ story at $2.0 \%$ drift. The flexural cracks on beams are observed around the gap, and it does not develop to the beam column joint finally. This gap helps the frame form a beam side sway mechanism. The crack on the floor slab is parallel to the transverse beam. The cracks on the columns with wing wall concentrated at the bottom of the columns in $1^{\text {st }}$ and $2^{\text {nd }}$ story, indicating the inflection points of the column is relatively higher. On the other hand, the cracks are observed at the top of the columns in $3^{\text {rd }}, 4^{\text {th }}, 5^{\text {th }}$ story, and it indicates the inflection points are lower. The gap width around center hanging vertical walls is designed not to contact the spandrels until $3.0 \%$ story drift, but they contact due to the flexural deformation of the beam members.

Maximum crack widths of each member during each loading cycle at peak displacement and unloading are shown in Fig.8. Maximum crack widths for $2 \mathrm{~F}$ beam at peak displacement and unloading rapidly increase during $R=0.5 \%$ cycle, since those cracks near a structural gap opened significantly due to yielding of beam longitudinal bar. Maximum residual crack width of beam reaches to $5.0 \mathrm{~mm}$ at $R=1.0 \%$ cycle. Maximum crack widths of spandrell walls are smaller than those beams. Regarding cracks observed at $1 \mathrm{~F}$ center column, some difference between maximum crack width of column front face and column side faces is observed during small drift angle. However, crack width of column side faces become almost equal to that of column front face after $R=1.0 \%$ cycle, since the cracks of column front face connect to those of column side face as lateral deformation increases. Maximum crack width of wing walls is relatively smaller than that of column as shown in this figure. 


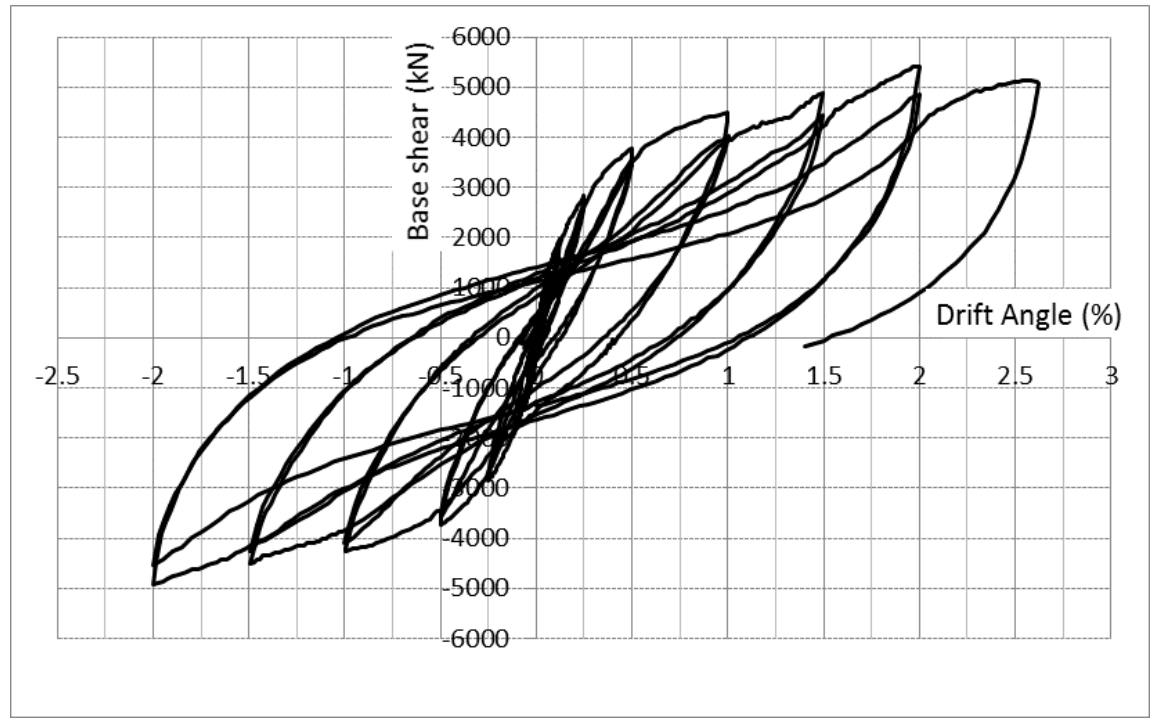

Figure 6: Load-displacement relation.

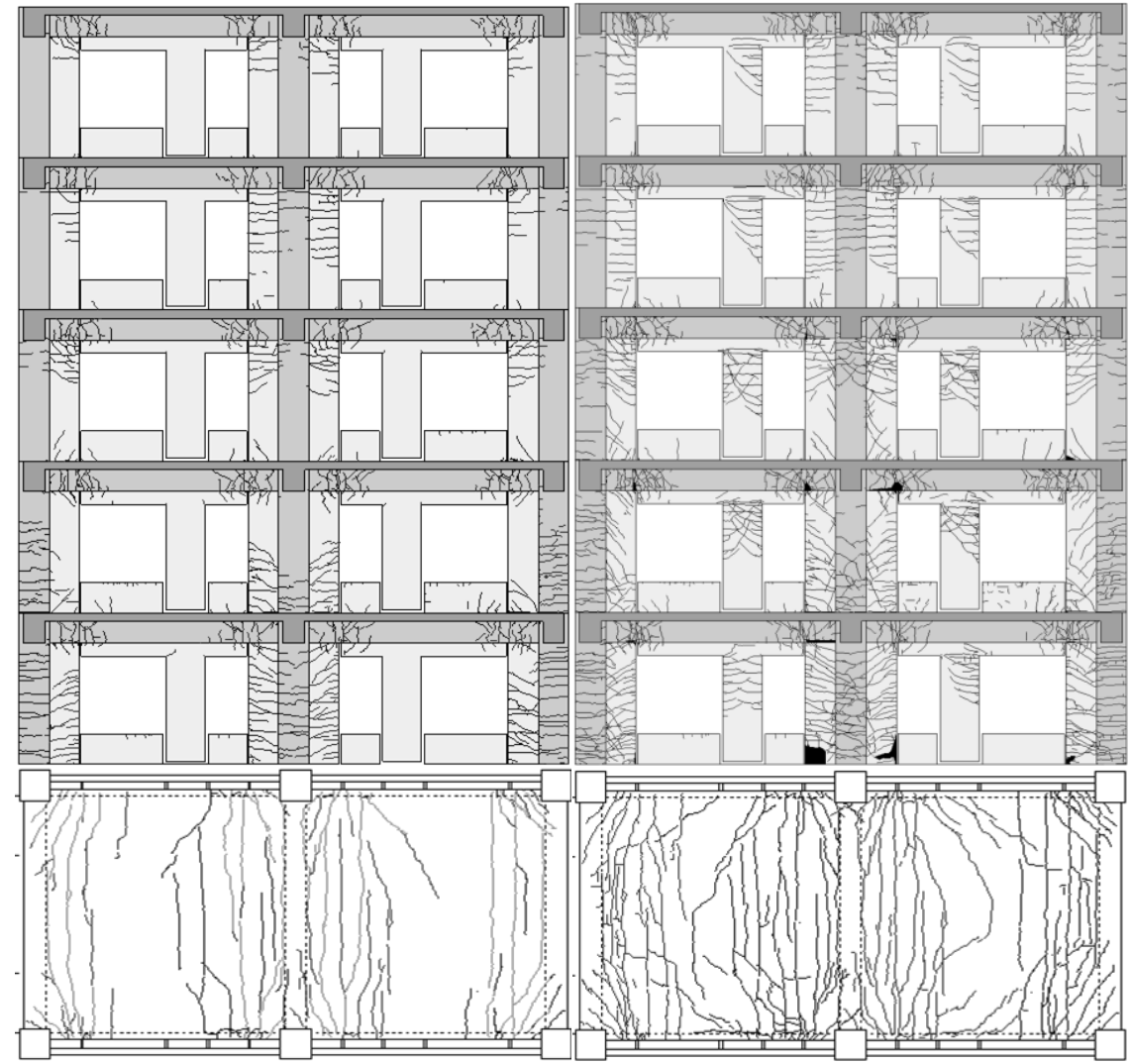

(a) $0.50 \%$ building drift angle

(b) ultimate state

Figure 7: Cracking pattern on the specimen.

\section{DAMAGE CLASS FOR STRUCTURAL ELEMENTS}

In Japan, "Guideline for Post-earthquake Damage Evaluation and Rehabilitation", published by the Japan Building Disaster Prevention Association [3], is commonly used for residual seismic capacity evaluation of buildings damaged due to an earthquake. Damage classification of structural elements is performed based on the damage definition shown in Table 1 . Structural elements are classified into one of five categories (I through V). Next, the seismic capacity reduction factor $\eta$ which corresponds to the damage class is calculated as a residual seismic capacity index of each element. Finally, residual seismic capacity of each story is evaluated using residual seismic capacity ratio $\mathrm{R}$.

Results of damage classification for some structural elements of the specimen are shown in Table 2. Generally damage class of column with wall or beam with wall is given in practice as one structural component, however first of all, damage class is shown for columns, beams and walls separately considering damage condition of each part.

2F beam: The damage class is determined by crack width, since some cracks concentrates around the structural gap and compression damage of concrete is slight. At the $R=1.0 \%$ 

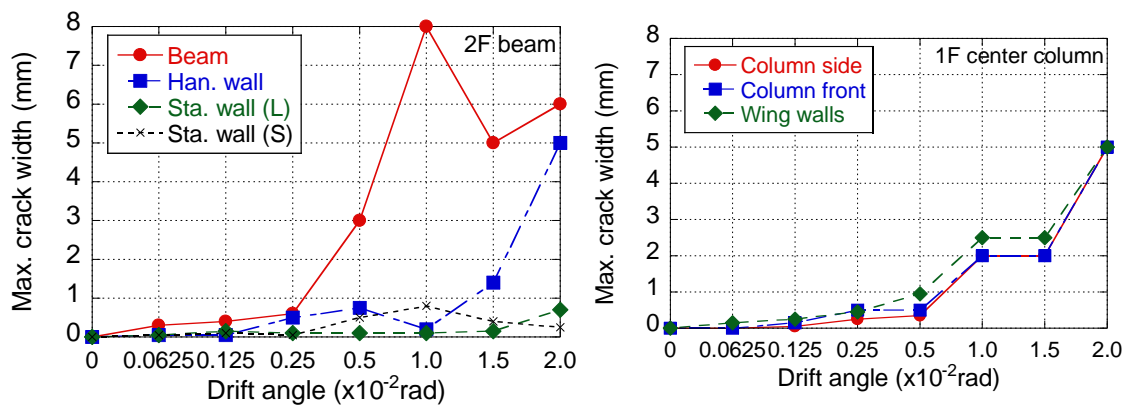

(a) At peak displacement
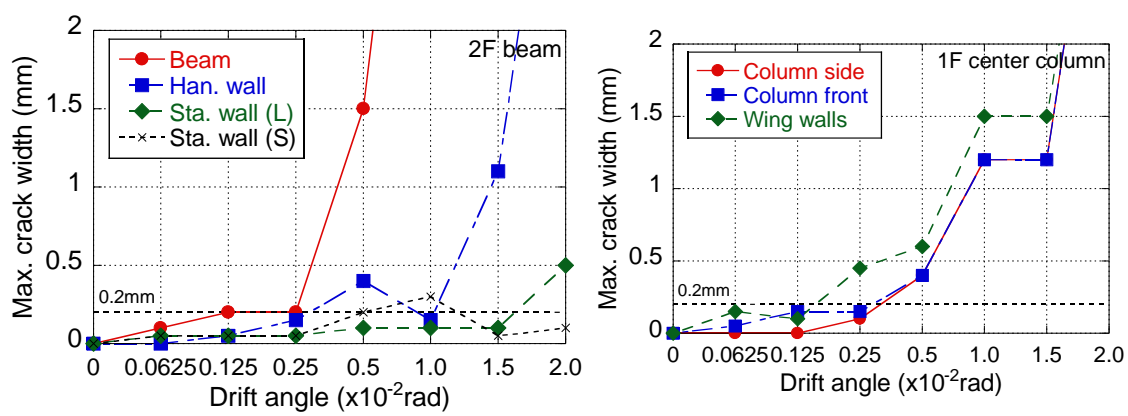

(b) At unloading

Figure 8: Maximum crack width.

cycle, the damage class is judged as IV because of some significant cracks near structural gaps seen in Fig.9. Most cracks on spandrel walls are slight as their widths are less than $0.2 \mathrm{~mm}$, which repair is not necessary, because of the effect of structural gaps. Regarding the damage of interior beamcolumn joint, any damage is not observed seen in Fig.10, since wing walls have hinge relocation function to beams.

$1 \mathrm{~F}$ center column: The damage class of the column is determined by crack width until the $R=0.5 \%$ cycle, since concrete spalling is not observed. At the $R=2.0 \%$ cycle, the damage class is judged to be $\mathrm{V}$ due to core concrete crushing at the column base. On the other hand, the damage class of wing walls was determined by crack width until the $R=1.0 \%$ cycle because concrete spalling is hardly observed. Then, core concrete crushing at the wing wall base lead to damage class $\mathrm{V}$ at the $R=1.5 \%$ cycle. The horizontal load carrying capacity of column with wing walls will be deteriorated due to the wing wall damage, however, the member will be repairable because the column still had enough horizontal and vertical load carrying capacity. After the $R=2.0 \%$ cycle, core concrete crushing of wing walls progress and vertical reinforcements of the wing wall fracture at the wall base.

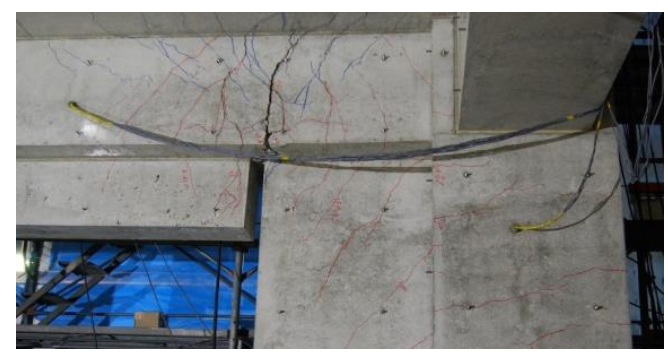

Figure 9: Beam end in the $3^{\text {rd }}$ floor.
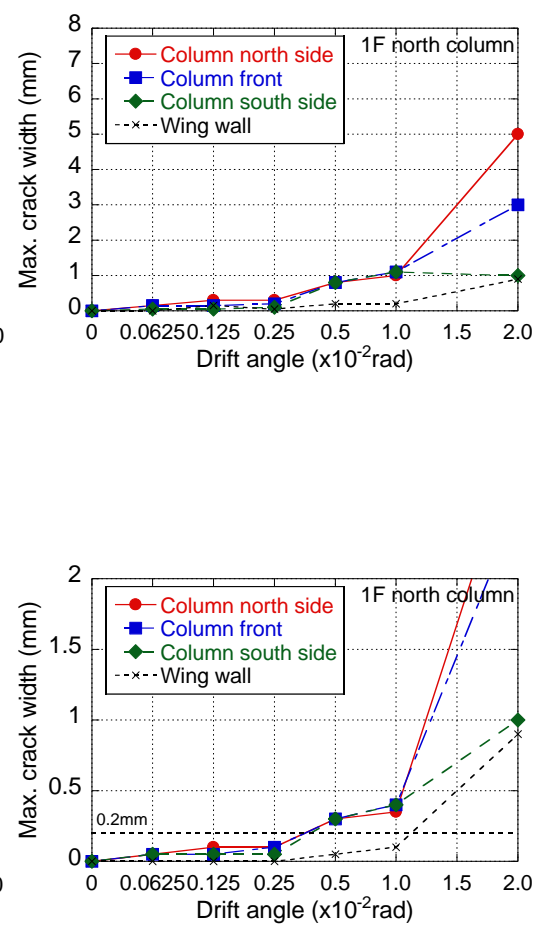

Drift angle $\left(\times 10^{-2} \mathrm{rad}\right)$

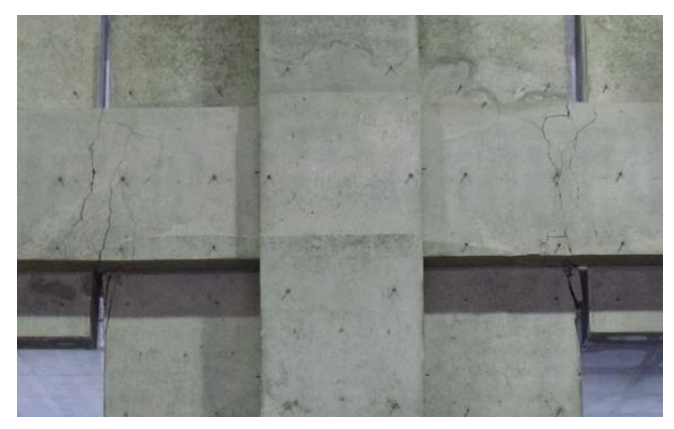

Figure 10: Interior beam-column joint in the $2^{\text {nd }}$ floor.

$1 \mathrm{~F}$ north column: As observed damage is slight until the $R=1.0 \%$ cycle, the damage classes of the column and wing wall are less than II and I, respectively. The damage class of the column increases to IV at $R=2.0 \%$ cycle. The damage class of the wing wall is III with cover concrete spalling, while judgement by maximum residual crack width gives damage class II. The cause is the column is located on the tension side when the wing wall is compressed during the negative side loading. It is assumed that the member still has enough seismic capacity and the damage is repairable.

2F slab: The damage class of slab is determined by crack width, since concrete spalling is hardly observed as shown in the previous section. The results of damage classification of the beam top face and slab are similar. The damage class of the beam top face is equal to or smaller than that of beam during all loading cycles.

Damage classification for columns with wing walls and beams in loading direction considering measured maximum residual crack width and concrete spalling is performed. Damage class of a column with wing wall is determined as the larger of the damage classes of the column and wing walls. Residual crack width of the slab is not considered as damage classification of 
Table 1: Definition of Damage class for R/C members [3].

\begin{tabular}{|c|l|}
\hline Damage class & \multicolumn{1}{|c|}{ Description of damage } \\
\hline I & Visible narrow cracks on concrete surface (Crack width is less than or equal to 0.2mm) \\
\hline II & Visible clear cracks on concrete surface (Crack width is approximately 0.2-1.0mm) \\
\hline III & Local crush of cover concrete, Remarkable wide cracks (Crack width is approximately 1.0-2.0mm) \\
\hline IV & $\begin{array}{l}\text { Remarkable crush of concrete with exposed reinforcing bars, Spalling off of cover concrete (Crack width is more } \\
\text { than 2.0mm) }\end{array}$ \\
\hline V & $\begin{array}{l}\text { Buckling of reinforcing bars, Cracks in core concrete, Visible vertical and/or lateral deformation in columns } \\
\text { and/or walls, Visible settlement and/or inclination of the building }\end{array}$ \\
\hline
\end{tabular}

Table 2: Damage class for structural elements.

\begin{tabular}{|c|c|c|c|c|c|c|c|c|c|c|}
\hline \multirow{2}{*}{$\begin{array}{c}\text { Drift angle } \\
{[\%]}\end{array}$} & \multicolumn{4}{|c|}{$2 \mathrm{~F}$ beam } & \multicolumn{2}{|c|}{$1 \mathrm{~F}$ center column } & \multicolumn{2}{|c|}{$1 \mathrm{~F}$ north column } & \multicolumn{2}{|c|}{$2 \mathrm{~F}$ slab } \\
\hline & B & HW & SW1 & SW2 & $\mathrm{C}$ & WW & $\mathrm{C}$ & WW & BT & $\mathrm{S}$ \\
\hline 0.0625 & \multirow{3}{*}{ I } & \multirow{2}{*}{ I } & \multirow{5}{*}{ I } & \multirow{3}{*}{ I } & \multirow{3}{*}{ I } & \multirow[b]{2}{*}{ I } & \multirow{3}{*}{ I } & \multirow{5}{*}{ I } & & \\
\hline 0.125 & & & & & & & & & I & I \\
\hline 0.25 & & \multirow{3}{*}{ II } & & & & & & & & \\
\hline 0.5 & III & & & \multirow{4}{*}{ II } & II & & & & II & \\
\hline 1.0 & \multirow{3}{*}{ IV } & & & & & III & & & III & III \\
\hline 1.5 & & III & \multirow{2}{*}{ II } & & & \multirow{2}{*}{ V } & - & - & \multirow{2}{*}{ IV } & \multirow{2}{*}{ IV } \\
\hline 2.0 & & IV & & & V & & IV & $\mathrm{II}(\mathrm{III})$ & & \\
\hline
\end{tabular}

B: Beam, HW: Hanging wall, SW1: Standing wall (large), SW2: Standing wall (small),

C: Column, WW: Wing wall, BT: Beam top face, S: Slab

beam in this paper. The residual seismic capacity ratio is calculated based on the simplified procedure shown in Ref [3] considering the seismic capacity reduction factor $\eta$ for a ductile column under the assumption that each column has the same ultimate strength. The relationship between the factor and damage class is shown in Table 3. Moreover, in the case damage class of the beams is larger than damage class of the column connecting to the beam, damage class of the column is replaced by one of the beam [3].

Damage classes of columns with wing walls and beams at each loading cycle are shown in Fig.11. As shown in this figure, many beams show a much larger damage class than the columns connected to the beams, since beam deformation is concentrated to the structural gap around beam ends. There is not much difference between damage classes of columns and beams ( 0 or I) until $R=0.25 \%$ cycle. Damage classes of beams is greater than those of columns except the first floor column after the $R=0.5 \%$ cycle.

\section{BUILDING DAMAGE RATING}

Damage rating of the whole building are performed based on Ref [3]. The residual seismic capacity ratio $\mathrm{R}$ is calculated by equation (1). In this equation, $A_{\text {org }}$ means total number of column with wall and $A_{j}$ means total number of damaged one and is calculated by product Aorg and the factor $\eta$. The relationship between damage rating and residual seismic capacity ratio $R$ is shown in Table 4 .

$\mathrm{R}[\%]=\frac{\sum_{j=0}^{5} A_{j}}{A_{\text {org }}} \times 100$

The ratio and damage rating of each floor are shown in Fig.12 and Table 5, respectively. The residual seismic capacity ratio and the damage rating of the first floor during the $R=1.5 \%$ cycle are shown as a reference with "*”, because all cracks were not measured in this cycle. As shown in Fig. 12 and Table 5 , damage ratings of all floors are "Slight" until the $R=0.125 \%$ cycle. Then, the damage rating increases in order from the lower floor as lateral loading increases. The maximum damage rating is "Light" during the $R=0.25 \%$ cycle, "Moderate" during the $R=0.5 \%$ cycle, and "Heavy" after the $R=1.0 \%$ cycle. After the $R=1.5 \%$ cycle, all floors are assessed as "Heavy". The story shear force of the first floor is increasing during the $R=0.5 \%$ and $1.0 \%$ cycles, in which damage rates are moderate and severe. This damage rating method based on a domestic standard turned out to give a conservative result for this specimen. This implies that the method gives a conservative result for ductile buildings, such as relatively new buildings designed after 1981. In order to apply the method for new buildings, the damage evaluation method for structural elements should be advanced more in the future.

\section{CONCLUSIONS}

Damage analysis and building damage rating by the Japanese Guideline were performed for a full-scale five-story R/C building specimen. Obtained findings are listed below.

- A limited number of cracks on beams near structural gaps opened significantly. As a result, damage class is determined by residual crack width. Most cracks on spandrel walls were slight as their widths were less than $0.2 \mathrm{~mm}$, which repair is not necessary, because of the effect of structural gaps.

- Columns and wing walls showed different tendencies in damage progress and physical damage quantity such as numbers of crack, crack width and concrete spalling area respectively. The concrete spalling area ratio of wing walls was substantially larger than that of the column in the case of the center column at the $1^{\text {st }}$ floor. $1 \mathrm{~F}$ north column was located on the tension side when the wing wall was compressed during the negative side loading. As a result, the damage of 

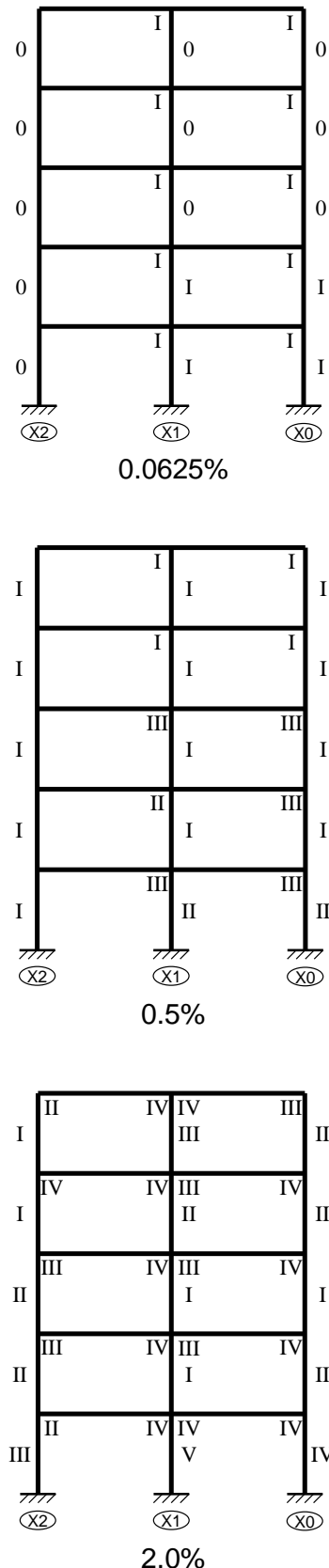
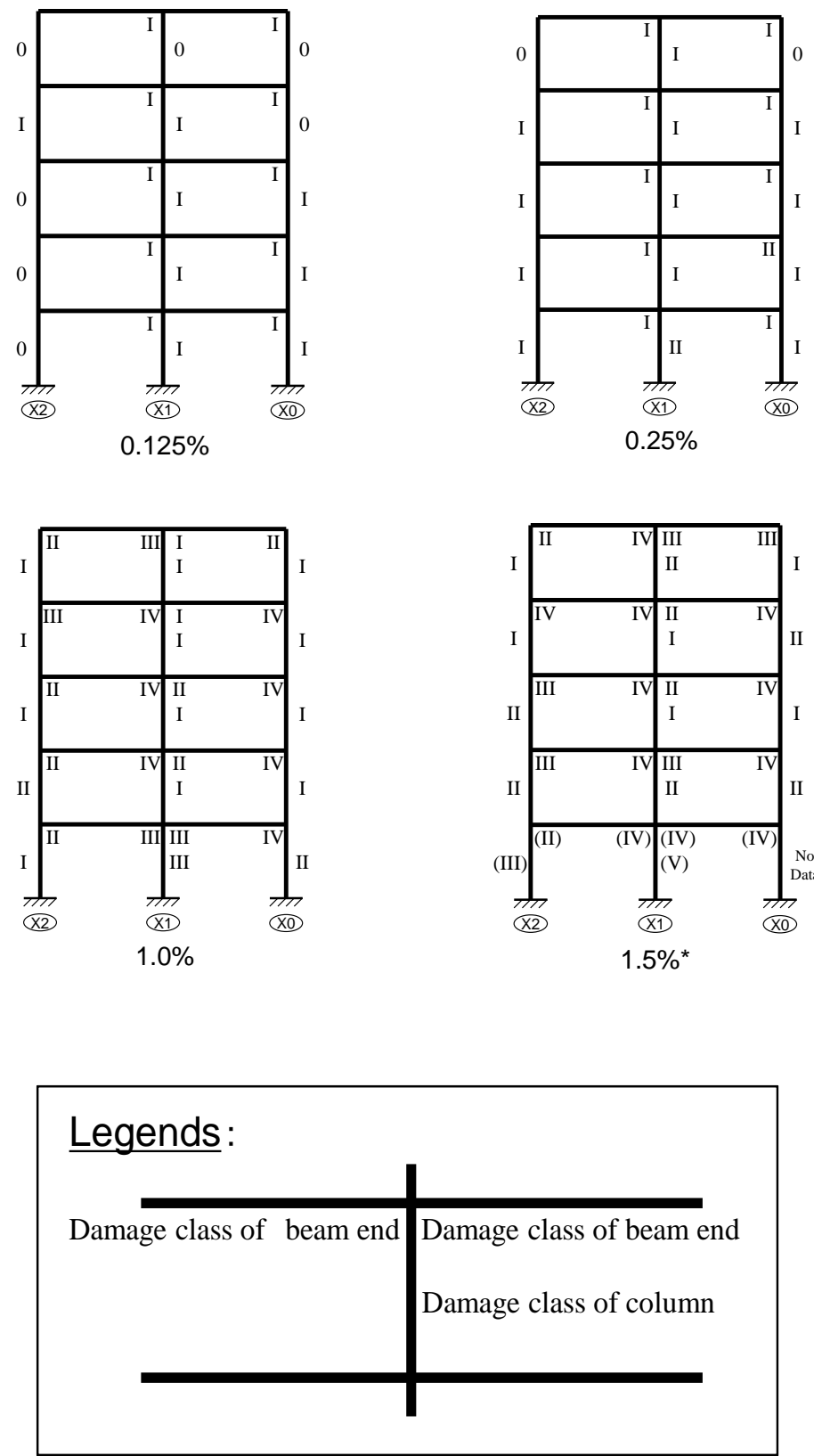

Figure 11: Damage class of each structural element.

the column was larger than that of the wing wall in terms of residual crack length and concrete spalling area. These results indicate that the damage of column and wing walls should be evaluated separately.

- Many beams showed much larger damage class than columns connected to the beams. Until the $R=0.25 \%$ cycle, there was not much difference between damage classes of columns and beams ( 0 or I). Damage classes of beams increased more than those of columns except for the first floor columns after the $R=0.5 \%$ cycle. The maximum damage rating is "Light" during the $R=0.25 \%$ cycle, "Moderate" during the $R=0.5 \%$ cycle, and "Heavy" after the $R=1.0 \%$ cycle. Applied damage rating method turned out to give overly conservative results. This implies that the method gives a conservative result for ductile buildings, such as relatively new buildings designed after 1981. In order to apply the method for new buildings, the damage evaluation method for structural elements should be advanced more in the future.

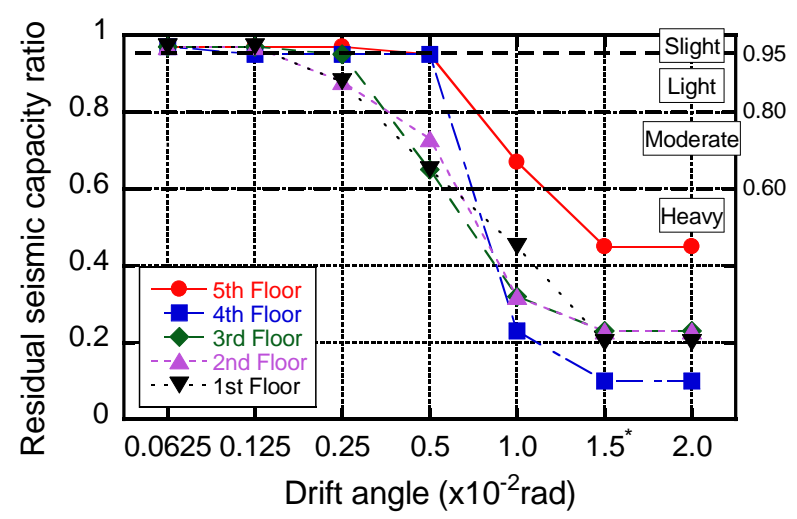

Figure 12: Residual seismic capacity ratio $R$ for building level. 
Table 3: Relationships between damage class and seismic capacity reduction factor $\eta$ for ductile column.

\begin{tabular}{|c|c|}
\hline Damage class & $\eta$ \\
\hline I & 0.95 \\
\hline II & 0.75 \\
\hline III & 0.5 \\
\hline IV & 0.1 \\
\hline V & 0 \\
\hline
\end{tabular}

Table 4: Relationships between damage rating and residual seismic capacity ratio $R$.

\begin{tabular}{|c|c|}
\hline Damage rate & $\mathrm{R}(\%)$ \\
\hline slight & $\geq 95$ \\
\hline minor & $80 \leq \mathrm{R}<95$ \\
\hline moderate & $60 \leq \mathrm{R}<80$ \\
\hline severe & $R<60$ \\
\hline collapse & $\approx 0$ \\
\hline
\end{tabular}

Table 5: Damage rating of each story.

\begin{tabular}{|c|c|c|c|c|c|}
\hline Building Drift angle[\%] & 5th story & 4th story & 3rd story & 2nd story & 1st story \\
\hline 0.0625 & \multirow{4}{*}{ Slight } & \multirow{4}{*}{ Slight } & \multirow{3}{*}{ Slight } & \multirow{2}{*}{ Slight } & \multirow{2}{*}{ Slight } \\
\hline 0.125 & & & & & \\
\hline 0.25 & & & & Light & Light \\
\hline 0.5 & & & Moderate & Moderate & Moderate \\
\hline 1.0 & Moderate & \multirow{3}{*}{ Heavy } & \multirow{3}{*}{ Heavy } & \multirow{3}{*}{ Heavy } & \multirow{3}{*}{ Heavy } \\
\hline $1.5 *$ & \multirow{2}{*}{ Heavy } & & & & \\
\hline 2.0 & & & & & \\
\hline
\end{tabular}

\section{ACKNOWLEDGEMENTS}

This study was carried out by a joint study of National Technology Development Project of MLIT "Development of function sustaining technologies for buildings used as Disaster Prevention Bases" (2013 2016) and Priority Research Program of BRI "Development on Seismic Design Method for Building with Post-Earthquake Functional Use" (2013 2015), The grand design of the test was planned by Technical WG (Chairman Professor Teshigawara from Nagoya University). The static loading test was carried out by Structural Engineers of Nishimatsu Construction Co. Ltd., Hazama Ando Corporation, Kumagai Gumi, Sato Kogyo Co. Ltd, Toda Corporation, Fujita Corporation, and Maeda Corporation. The efforts in measuring various damage of concrete for damage analysis by Tokyo Institute of technology, Tokyo University of Science and Tohoku University are gratefully acknowledged.

\section{REFERENCES}

1. Maeda M and Kang DE (2009). "Post-earthquake damage evaluation of reinforced concrete buildings". JCI Journal of Advanced Concrete Technology, 7(3): 327-335.

2. Kabeyasawa T, Mukai T, Fukuyama H, Kato H, Suwada H, Teshigawara M and Kusunoki K (2016). "A full scale static loading tests on five story reinforced concrete building utilizing columns with wing walls". AIJ Journal of Structural and Construction Engineering, 81(720): 313322.

3. Nakano $\mathrm{Y}$, Maeda $\mathrm{M}$, Kuramoto $\mathrm{H}$ and Murakami $\mathrm{M}$ (2003). "Guideline for post-earthquake damage evaluation and rehabilitation of RC buildings in Japan". Proceedings of the 2nd Korea-Japan Workshop on New Direction for Enhancement of Structural Performance-Formulation, Verification, and its Application, Yokohama, Japan, 41 4-17. 